\title{
Going Online? China's Response in Higher Education System to the Pandemic
}

\author{
Tian LIU and Ying HUANG \\ Faculty of Education, Western University, London, Ontario, Canada \\ tliu455@uwo.ca;yhuang36@uwo.ca
}

\begin{abstract}
Since the early march of 2020, higher education institutions around the world shut down quickly because of the outbreak of covid-19. This article addresses China's response to this unprecedented pandemic in terms of a nationwide school closure. This article introduces how Chinese higher institutions use different strategies to launch online education under the initiative entitled "Ensuring Learning Undisrupted when Classes are Disrupted" from the Ministry of Education. The article also provides brief introduction on China's online education initiative in a global context. Concerns of online education discussed in this article include equitable access to online education, challenges of curriculum design, and academic integrity. Practical suggestions are therefore offered based on North American experience. Finally, this article concludes the critical impact of online education on Chinese higher institutions during and even after this pandemic.
\end{abstract}

\section{Keywords}

COVID-19 - higher education - online education - China

In the aftermath of the World Health Organization's declaration of the COVID-19 as a pandemic on March 11, 2020, higher education institutions around the world were shutting down quickly. Instead of going to campus for face-to-face classes, students are shifting to virtual classrooms via the Internet. According to the United Nations Educational, Scientific and Cultural Organization (UNESCO), these nationwide closures are impacting almost $70 \%$ of the world's student population (UNESCO, 2020a). The COVID-19 crisis has created 
a planetary disruption to higher education, and most of the higher education institutions moved to online education during this pandemic. The consequences for higher education of the COVID-19 crisis will be far-reaching, complex and may only really emerge once a degree of normality returns (UNESCO, 2020b)

\section{1 \\ China's Response}

With the largest student population of higher education in the world, China has quickly responded to this unprecedented pandemic in terms of a nationwide school closure. The Ministry of Education (the MOE) launched an initiative entitled "Ensuring Learning Undisrupted when Classes are Disrupted". On February 6, 2020, the MOE released a guideline for online teaching and learning from elementary schools to universities, while all kindergartens were closed at the same time. The Guideline aggressively prescribed detailed protocols for online education in China (MOE, 2020a).

Official data show that as of May 8, 2020, there are 1,454 Chinese postsecondary schools switching to online education, and 1.07 million online courses are instructed by 1.03 million teachers in higher education in China (MOE, 2020b). These courses cover 12 major areas, including Science, Engineering, Agriculture, Medicine, Economics, Management, Law, Arts, History, Art, and Education. Courses are mainly delivered via synchronous mode, asynchronous mode, massive open online course (MOOC), and distance guidance, etc. In total, there are 17.75 million post-secondary students learning online during this pandemic, according to MOE. A recent statistic from MOE shows that about $80 \%$ of the higher education students feel satisfied with online education method (China Education Online, 2020). Some open MOoc websites that Chinese students can learn include Zhihuishu, Xuetangx, cnм ooc, University Open Online Courses, Coursera, EdX, and Udacity. Online courses are also delivered via platforms including DingTalk, Zoom, Classin, Wechat group, and QQ group. Data from MOE shows that China now has more than 12,500 MOOC courses, which have been studied more than 200 million times. As such a leading Mоoc provider, China plans to hold the Global mooc Conference in Beijing in November 2020 (China Education Online, 2020).

In addition to offering online education to domestic students, some higher education institutions in China also launched online education project globally. The International Institute of Online Education (IIOE) initiative is one of these pioneering projects. IIOE initiative is proposed by the International Centre for Higher Education Innovation at the University of Science and 
Technology of South China under the auspices of UNEsCo (UNESCO-ICHEI) with its partner higher education institutions (HEIS) in developing countries in Africa and Asia-Pacific, and its partner enterprises and HEIs in China (IIOE, 2020). It was proposed in the bigger context of China's Belt \& Road initiative, and aims to provide high-quality online courses for HEIs in Belt \& Road countries. All together China has made a timely response in its higher education system to this pandemic, becoming a leading state utilizing online technology as the primary approach to teaching and learning.

The pandemic is obviously the major reason that pushes online education to the center stage. Another reason is the rapidly advanced technology and $5 \mathrm{G}$ networks in China. Over the last two decades, online education was not regarded as equal as face-to-face education in China. Very few colleges and universities use online format in their teaching and learning for formal degree programs, especially at the graduate level. During this pandemic, it is widely believed and expected that online education shall play a critical role in learning and teaching. With the support from both policy makers and new technology, online education has proved itself a reliable and practical way for education as a global trend for the future.

It is evident that online education is the only option for schools and universities to utilize in order to continuously provide education in this global crisis, as countries around the world continue to enforce social distancing and other hygiene measures to flatten the pandemic curve. Facing the new normalcy, many Chinese universities have intensively provided faculty training to deliver more effective and interactive online courses to students.

Comparing to those in North America, there were limited online degree programs in China and all online degree programs abroad were not recognized by the official certification system in China. However, higher education leaders, in order to be prepared for uncertain futures and financial challenges, must be equipped with options to be able to meet strategic plan goals (Sutton, 2014). This COVID-19 pandemic is one example of these uncertain futures. During the pandemic, the whole world has made different strategies or changes in educational sectors to cope with this crisis. Educational Testing Service (2020) recently announced that тOEFL (Test of English as a Foreign Language) developed a home edition that allows students to take TOEFL at home because of the pandemic. Online technology is and will shift many "normal practices".

It is no doubt that this pandemic has changed the world in various aspects: from our personal life such as how we wash our hands and keep social distancing, to government policy making, economy, and globalization. Moving to online education is one of the changes that happen in educational sector. Convenience is often regarded as the most prominent advantage of online 
education, especially for adult learners (Brown, 2017). During this pandemic, convenience means students can stay at home and do not need to travel to campus in order to self-isolate and maintain social distancing. This unprecedented pandemic has opened a new stage of educational provision in human history. The combination of both online and face-to-face has become the new normal to teaching and learning in China.

\section{Concerns}

The pandemic is an excellent opportunity to examine the impact of online teaching and learning, while some concerns arise from homeschooling initiatives.

First, not every student can access the Internet and smart devices for their online learning; equity in education has been widened during the outbreak of Covid-19. In China, since there are 56 to 80 million people who did not have access to the Internet by 2018; another 480 million people did not access for other reasons (Zhong, 2020). When the problem occurs with the pandemic, it means school-aged kids' regular schooling may be disrupted. This significant gap illustrates the difficulty of making online learning available to these families, especially for those in poverty and in rural area. For example, there were two siblings who had to use their father's cell phone for online courses during the shutdown in a rural area. When the pandemic flattened the curve, the father had to go back to work in the neighbour city, so he took his cell phone. Then the kids have left no access to online lecturing (Zhong, 2020).

Secondly, the current curriculum makes online education challenging and overwhelming for teachers, students and parents. Since most of the learning tasks and progress are monitored and assessed by teachers in China, online learning shifts the responsibility to students themselves or their parents. Most of lessons are recorded before class, there is no simultaneous interaction between teachers and students. Obviously, self-motivation and self-regulation are more demanded for online learning as opposed to face-to-face learning. Consequently, the existing curricular and pedagogical structure is not easily applicable to online teaching and learning. Canadian educators suggest that course content should be adjusted with the shortened school year, potentially moving it partially to the next level to ensure teaching and learning quality (Srivastava and Yamey, 2020).

Thirdly, academic integrity is too an unavoidable issue in online teaching and learning. Most courses have exams as their final evaluation, which are always taken place in classrooms under proctoring in China. While online 
proctoring is unrealistic, some learners may commit cheating for whatever reasons they might be. Since all assignments are handed in online, plagiarism could be a serious issue to be concerned. Higher education institutions in Canada offer alternative evaluation forms to replace the regular exams: 1 ) change the final exam to an essay/reflection, 2) calculate final grades based on completed portions (only if greater than $60 \%$ ). All the written assignments are submitted through online originality checking systems such as the Turnitin to detect plagiarism.

\section{3}

\section{Implications}

The pandemic is indeed a global crisis for humankind, but it also provides "windows of opportunity" for significant changes in social-political regimes (NORRAG, 2020). Yuval Noah Harari (2020) also argues that a lot of short-term solutions are becoming a fixture of life. They accelerate historical evolution. For education during CoviD-19, the most critical trend emerged in online learning.

The ongoing online learning reveals the impact of technology platforms and products (Patil, 2020). Thanks to these technologies, learning is not entirely disrupted during school closure. However, the shortcoming of existing platforms is undeniable as well. For example, numerous academic conferences (e.g. CSSE, AERA) are cancelled because there is none virtual platform that can hold thousands of participants in various discussion forums. The crisis can serve as a pilot trial of our online learning tools; now, it is time to improve and prepare for future emergencies.

Last and most importantly, it has been urgent how may online teaching and learning be backed up by education policies and how may resources for teaching and learning be remobilized. Strong leadership, proper training, and multilevel collaboration should be enforced, so that moving everything online will not overwhelm teachers, students and parents (UNESCO, 2020c). Stakeholders should act decisively to ensure effective learning and teaching amid the covid-19. Curriculum development and enforcement are going to be a different professional work than usual. It is time to reconsider what is essential in teaching and learning that needs to be refined and improved.

\section{References}

Brown, C. G. (2017). The Persistence and Attrition of Online Learners. School Leadership Review, 12(1), 7 . 
China Education Online (2020, June 15). Ten important tasks in 2020, by Wu Yan, director of the higher education department of higher education, Ministry of Education of China. https://news.eol.cn/yaowen/202006/t20200615_1733449.shtml.

Educational Testing Service. (2020, May). тоEfL iBT Special Home Edition. https:// www.ets.org/s/cv/toefl/at-home/.

Harari, Y. N. (2020, March 20). Yuval Noah Harari: the world after coronavirus: Free to read. https://www.ft.com/content/19d90308-6858-11ea-a3c9-1fe6fedcca75.

International Institute of Online Education. (2020, May). Who we are. https://iioe.ichei .org/web/about.

Ministry of Education of China (MOE). (2020, February 6). Guideline of implementing information technology to support teaching and learning during novel coronavirus from the Leading Group of the MOE for Novel Coronavirus Prevention and Control. http://www.moe.gov.cn/srcsite/A16/s3342/202002/t20200214_421005.html.

Ministry of Education of China (MOE).(2020, May 14). Press Conference: Introduction of online education of elementary school to university during pandemic and next plan. http://www.moe.gov.cn/fbh/live/2020/51987/.

Patil, L. (2020, May 18). Disaster Philanthropy: Exploring the Power and Influence of the Private Sector and For-Profit Philanthropy in Pandemic Times. https://www.norrag .org/disaster-philanthropy-exploring-the-power-and-influence-of-the-privatesector-and-for-profit-philanthropy-in-pandemic-times-by-lara-patil/.

Srivastava, P., \& Yamey, G. (2020, May 12). Opinion: Quebec is reopening schools, but should it be hitting the brakes instead? https:/www.theglobeandmail.com/opinion/ article-quebec-is-reopening-schools-but-should-it-be-hitting-the-brakes/.

Sutton, R. (2014). Unlearning the Past: New Foundations for Online Student Retention. Journal of Educators Online, 11(3), 30. https://doi.org/10.9743/JEO.2014.3.5.

United Nations Educational, Scientific and Cultural Organization (UNESCO). (2020a, May). COVID-19 Educational Disruption and Response. https://en.unesco.org/ covid19/educationresponse.

United Nations Educational, Scientific and Cultural Organization (UNESCO). (2020b, May). coVID-19 education response webinar: implications for the global higher education campus; synthesis report.https://unesdoc.unesco.org/ark:/48223/pfooo0373520.

United Nations Educational, Scientific and Cultural Organization (UNESCO). (2020c). COVID-19 crisis and curriculum: sustaining quality outcomes in the context of remote learning. Retrieved from https://unesdoc.unesco.org/ark:/48223/pfooo0373273 .locale $=$ en.

Zhong, R. (2020, Mar 17). The Coronavirus Exposes Education's Digital Divide. The New York Times. https://www.nytimes.com/2020/03/17/technology/china-schoolscoronavirus.html. 